\title{
Theory-related translation research: Some thoughts on methodology
}

\begin{abstract}
The article illustrates some methodological principles for translation research and for writing theory-related research papers. A number of postulates are formulated with respect to basic structural dimensions of organizing research papers (working hypothesis, 'state of the art' in research, solution proposal and validity test). Examples for normcompliant behavior are given. Since the problem of writing the 'state of the art' of research seems to be one of the major problems facing young scholars, particular emphasis is given to this aspect.
\end{abstract}

\section{Introduction}

Theory-related translation research and its publication as research papers $^{1}$ involve the formulation and logical development of abstract thought. It is, therefore, often considered to be beyond methodology and, especially by $\mathrm{PhD}$ students, misunderstood as 'a book of seven seals'. This does not have to be necessarily true and the misconception may partly be due to the fact that the underlying ideas of theory-related research, e.g. the critical thinking and analysis involved in appreciating other theoretical approaches vis-a-vis one's own ideas, are rather abstract by nature and seem to resist a concrete step-by-step procedure in

1 In the following, I will refer to research papers only, although the same principles can be applied mutatis mutandis for planning or preparing research projects, especially $\mathrm{PhD}$ dissertations (cf. Gerzymisch-Arbogast forthcoming).

* Prof. Dr. H. Gerzymisch-Arbogast

Universität des Saarlandes

Philosophische Fakultät II, Fachrichtung 4.6

Englische Übersetzungswissenschaft

Postfach 151150

D-66041 Saarbrücken 
the sense of a clear-cut, hands-on methodology. ${ }^{2}$ However, abstract ideas and a concrete practical methodology in organizing them as research papers (or doctoral dissertations) need not contradict themselves as will be shown by illustrating some postulates for writing theory-related translation research papers by norm-compliant examples ${ }^{3}$. The postulates refer to basic structural dimensions of organizing research papers and are largely based on the guidelines established in Mudersbach's Prodainformad (1999:316-319). They are grouped in relation to the common set-up of academic papers (introduction, main part and conclusion) and are discussed in chapter two of the present article. Since the problem of writing the state-of-the-art analysis seems to be one of the major problems facing young scholars, particular emphasis is given to this aspect in chapter three.

Following these principles will not guarantee a good paper but they can serve as structural guidelines to plan and control the academic writing process. We hope that while the proposed norm-compliant methodology may, of course, have a certain tolerance for variants, it will be useful as a standard for quantifying deviations from the norm and thus be helpful in controlling one's own writing process and advising young scholars and doctoral students on how to set up research papers.

\section{Structural Postulates}

The postulates proceed from the assumption of an expert reader who is interested in learning about new theoretical developments in an economical way (as one of the principles of LSP communication ${ }^{4}$ ). For that reason, reading may be partial. It is also assumed that research papers are written for the purpose of informing expert colleagues of new re-

2 This may be the reason why PhD students complain that there is not enough guidance and very little expert literature, training material or documented expertise available on how to plan and organize research papers (cf., however, Gile 1991, 1999, and Gile et al. forthcoming), although research (i.e. writing research papers) forms an integral part of all academic translation and interpretation training programs.

3 The examples are not representative and are given for illustrative reasons only.

4 Cf. Fluck (1996:34ff.) where appropriate reference is made to other general principles of LSP communication and further literature on the subject is given. 
search approaches and/or results, i.e. for information and not for entertainment purposes. ${ }^{5}$

In order to facilitate the reading process for the expert reader we sug-

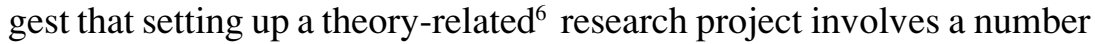
of steps and that the resulting research paper therefore should contain the following information:

- the object of the study or paper;

- its working hypothesis and objectives;

- an outline of its organizational or structural set up;

- the 'state of the art' in research (deficit analysis with problem statement on the basis of problem data);

- a theoretical suggestion closing the deficit identified (solution proposal);

- proof of the validity of the solution proposed vs. existing approaches (validity test);

- summary of results with (ideally) a perspective (desiderata for further research).

It is common practice to divide a research paper into three parts: an introduction, a main or central part and some concluding remarks (as an example cf. Theisen 1992:125-127) ${ }^{7}$. This paper will follow that set-up and roughly categorize the above postulates with respect to the structural set-up of the introduction (2.1), the structural set-up of the main or central part of the paper (2.2), and the organization of the concluding remarks $(2.3){ }^{8}$

5 We can also - in this context - refer to Grice's general maxims of 'be brief', 'be true', 'be relevant' (cf. Grice 1975:41-58).

6 Some of these principles apply to all research projects, some (e.g. solution proposal) only apply to theory-related research. While they may be considered general knowledge in the natural sciences, the T\&I research literature shows that it has largely neglected any standards for writing academic papers. For that reason this paper is directed primarily to $\mathrm{T} \& \mathrm{I}$ research.

7 Other literature on writing research papers is found in Standop (1998).

8 I will not go into the problem of the use of references because there is very recent literature available on that aspect (Gile 1999). 


\subsection{Organization of Introduction}

It is assumed that in the introduction the ideal expert reader expects to be informed about the object of the study, i.e. the theme or 'questioning' underlying the paper, its working hypothesis, its objective, and some information on how it is organized. This is useful information for economical reasons and may lead the reader to decide whether to go further into the paper (in its totality or in parts) or not. If this information is omitted, extra time is needed to appreciate the value of the paper and more time is necessary to follow the paper's logic.

\section{Example (1) of norm-compliant practice (introduction):}

\section{German Original \\ ZUR WECHSELWIRKUNG SITUATIVER UND KOGNITIVER PARAMETER BEIM FACE-TO- FACE-DOLMETSCHEN \\ Fadia Sami, Saarbrücken}

\section{Einleitung}

Die face-to-face Sprachmittlung trägt im Unterschied zum Kabinendolmetschen komplexere Züge. Diese ergeben sich aus einer Reihe verschiedenartiger Parameter, die in der Natur unmittelbarer kommunikativer Prozesse liegen. Die Aufdeckung solcher spezieller

Kommunikationsmuster und die Erörterung der Möglichkeiten, die die Interagierenden haben, diese zu erkennen und für die gegebene Situation umzusetzen, bilden den Gegenstand des vorliegenden Beitrags. Ziel der Untersuchung ist somit die Beschreibung der Handlungsweisen, der Informationsverarbeitung und der

Verstehensmechanismen in der kommunikativen face-to-face-Situation in bezug auf den

Dolmetscher... Die Analyse wird im ersten Teil makrostrukturell vorgenommen....Der Verstehensproze $\beta$, der beim sprachlichen Austausch im Individuum in Gang gesetzt wird, fällt unter die mikrostrukturelle Erklärungsebene und bildet somit den zweiten Teil des Beitrags, der auf psycholinguistisch-kognitive Fundamente gebaut ist.

(Sami 1999:241)
English Translation

ON THE INTERACTION OF SITUATIVE AND COGNITIVE PARAMETERS IN FACE-TOFACE-INTERPRETING

Fadia Sami, Saarbrücken

1 Introduction

Face-lo-face-interpretation, as opposed to cabininterpretation, is characterized by more complex features. These result from several different parameters, which lie in the nature of immediate communicative processes. Uncovering such special patterns in communication and the discussion of the possibilities the interactants have, to recognise these and put them into practice in the given situation, present the topic of this article. The aim of this study is to describe the behavior, the information processing, and the mechanisms of understanding in the communicative face-to-face-situation with view to the interpreter.... In the first part the analysis will be carried out on a macrostructural level... The process of understanding, which is triggered off in the individual during discourse, concerns the microstructural level and presents the second part of this article which is based on psycholinguisticcognitive foundations. 
This may vary in length, of course, with the topic of the paper and the space available and may not be explicit but implicit. Most common deviations from the norm include violations of the principle of 'Sachlichkeit' (matter of factness) in LSP communication, e.g. personal anecdotes or entertaining elements (at the cost of factual information), the inclusion of information not relevant to the topic or of information that appears elsewhere in the text like the methodological principles of the paper or an anticipation of results. Very often, information is given that is not directly related to the paper's topic. Including information that is not relevant is a very common violation of the norm (often seen in young scholars with little experience and/or thought given to the anticipated expert reader of the publication) and would be the case, for instance, if the author in the example above had started by generally defining 'interpretation' - the expert reader interested in the paper's topic can be assumed to know that.

\subsection{Organization of the main part of the paper}

It is assumed that in the main part of the paper, the expert reader expects to be informed about how the proposed theoretical approach is positioned in the field of the existing pertinent literature (especially in what assumptions it agrees with and in what assumptions it differs from other relevant theoretical approaches), whether the reasoning underlying the new model or theory is logically sustainable, and whether it is true, i.e. holds what it promises. These facts are crucial information for appreciating and valuing a theoretical approach as being inferior or superior and/or complementary to existing models (accuracy being another principle of LSP communication). If any of this information is omitted, it will be more difficult to appreciate the value of the model presented and accept it as a valid scholarly approach. Proceeding in this way also helps to ensure that the paper is 'coherent' in the sense of logically developing a thought rather than introducing 'new' unrelated ideas or information at an inappropriate place or time.

The postulates for a norm-compliant set-up of the main or central part of a theory-related research paper therefore include a presentation of the 'state of the art' in research (deficit analysis with problem statement), the development of a theoretical suggestion solving the problem identified (i.e. closing the deficit by proposing a solution) and proof of 
the validity of the solution proposed (validity test) vs. other existing approaches.

\subsection{1. 'State of the Art' in Research (Deficit Analysis)}

Proceeding again from the assumed expectations of an expert reader who is interested in the theoretical foundations and positions of the paper - reliable, up-to-date information about the nature of the theoretical problem (problem statement) and how it is positioned within the existing research published in the field (deficit analysis) forms the basis of any development of new thought. The 'state-of-the-art' analysis therefore is an account of what research has been done in the pertinent field so far, involving a critical pros-and-cons analysis of existing approaches with a statement of their merits and deficits at the time of publication of the paper. ${ }^{9}$

Example (2) of a norm-compliant practice (deficit analysis with problem statement):

9 This is why we can often read a statement like 'The manuscript for this article was completed in July 1999', (to avoid the criticism of missing up-to-date references). 
German Original

Heute kann man feststellen, da $\beta$ sich die

Mehrsprachigkeitsforschung als eigenständiger,

interdisziplinärer Forschungszweig etabliert hat.

Ein deutlicher Beleg für diese Behauptung ist, daß

Standardwerke zur Einführung zur Verfügung

stehen, z.B. Grosjean (1982) und in zweiter

Auflage Romaine (1995). Diese

Gesamtdarstellungen zeigen deutlich, daß sich

einige Themenschwerpunkte und

Forschungstraditionen herausgebildet haben. Zum

einen werden in Makroanalysen mehrsprachige

Sprachgemeinschaften untersucht. (...) Zusätzliche

Arbeitsschwerpunkte, die auf diese Weise

überprütbar werden, betreffen zum Beispiel .... Aus

allen diesen Untersuchungen wird deutlich, da 3

Mehrsprachigkeit ein Problemfeld bezeichnet, das

nur angemessen behandelt werden kann, wenn es

aus unterschiedlichen Perspektiven betrachtet

wird.... Die bereits angesprochene

Interdisziplinarität ist eine Möglichkeit dieser

Komplexität des Gegenstands gerecht zu werden....

Dennoch gibt es in der bisherigen Forschung ein

Defizit, das damit zu begründen ist, daß die

unterschiedlichen Ansätze noch nicht hinreichend

koordiniert sind und ihre Ergebnisse nicht im

notwendigen Umfang wechselseitig zur Kenntnis

nehmen. (...)

In dem hier skizzierten Kontext besteht für den

Sonderforschungsbereich die realistische Chance, zumindest die unterschiedlichen linguistisch-

philologischen Ansätze fä̀cherübergreifend zu

integrieren und somit auch in Methodik und

Theoriebildung innovativ zu wirken.... So gilt es,

der Frage nachzugehen, welche Gemeinsamkeiten

und Unterschiede im sprachlichen Wissen und in

den vielfältigen Formen des Gebrauchs zwei oder

mehr Sprachen feststellbar sind. (...)

Die Fragestellungen des Sonderforschungsbereichs

konzentrieren sich zudem auf zwei

Themenbereiche.....
English Translation

Today it can be said that research on

multilingualism has established itself as an

interdisciplinary branch of research in its own

iight. The availability of standard works for introduction, e.g. Grosjean (1982) and Romaine

(1995) in 2. Edition, is dear proof of this claim.

These general overviews clearly show that some

focal issues and research traditions have evolved.

First, multilingual language communities are

investigated in macroanalyses. (...) Further main

points for example concentrate, and thus are put to

the test, on ... It becomes clear from these studies,

that multilingualism describes a problem area

which can only be dealt with adequately by

looking at it from different perspectives... The above-mentioned interdisciplinarity presents a possibility of dealing with the complexity of the issue.

Until today, however, a deficit remains. The reason for this could lie in the lack of co-ordination of the different approaches and an insufficient mutual recognition of their results. (...)

In the context described here, the Research Center on Multilingualism stands the realistic dhance of integrating the different linguistic-philological approaches in an interdisciplinary way and thus bringing about innovations in methodology and the development of theories.... It is necessary to look into the question which common aspects or differences in terms of language knowledge and in terms of the diverse forms of the usage of two or more languges can be determined. (...)

Moreover, at the Research Center questions at issue focus on two areas....

(Sonderforschungsbereich Mehrsprachigkeit 1999:15-19) 
Depending on topic and space, again the problem and deficit analyses may vary in length and may be implicit or explicit. The most common problems encountered in this part of a research paper are related to

- presenting not enough problem-related information, mostly resulting from insufficient research into the problem and leading to incorrect information and/or misrepresentation of facts and thus violating the norm of accuracy in LSP communication;

- presenting too much information in an uncritical fashion, mostly resulting from insecurity of judgement and/or lack of critical thought and leading to an often random and unconnected summary of existing approaches without a comparative pros-and-cons analysis and often without any relationship to the problem under discussion or the author's own position vis-à-vis the approaches discussed;

- presenting non-relevant information (in terms of individual theses or even anecdotes) instead of factual information relating to an analysis of the theoretical problem under discussion.

Very often (and this is so particularly with renowned and/or experienced scholars) authors exclusively offer their own approaches, opinions and (sometimes factually unfounded) value judgements instead of discussing the merits and/or possible shortcomings of existing thought and weighing it against their own judgements within the relevant research context. Very often anectodal evidence is used as a substitute for factual analysis and while this may be entertaining, it violates the norm of 'Sachlichkeit' and economy in LSP communication and causes impatience with an expert reader who may be inclined not to take an approach presented in that way seriously. We will discuss this aspect in more detail in section three.

\subsubsection{Closing the Deficit: The Solution Proposal}

Again, we proceed from the assumed expectations of an expert reader who is interested in new theoretical approaches. His/her expectations will be fulfilled if a solution, i.e. a new thought, a new theoretical approach is presented that closes the deficit analyzed before. More specifically, this means that the solution presented must evolve logically from the theoretical deficit identified in the literature (and analyzed in the 
'state-of-the-art' research analysis) as the justification for presenting theoretical thought that claims to be innovative.

Example (3) for a norm-compliant solution proposal ${ }^{10}$ :

\section{English Original}

TABLE OF CONTENTS

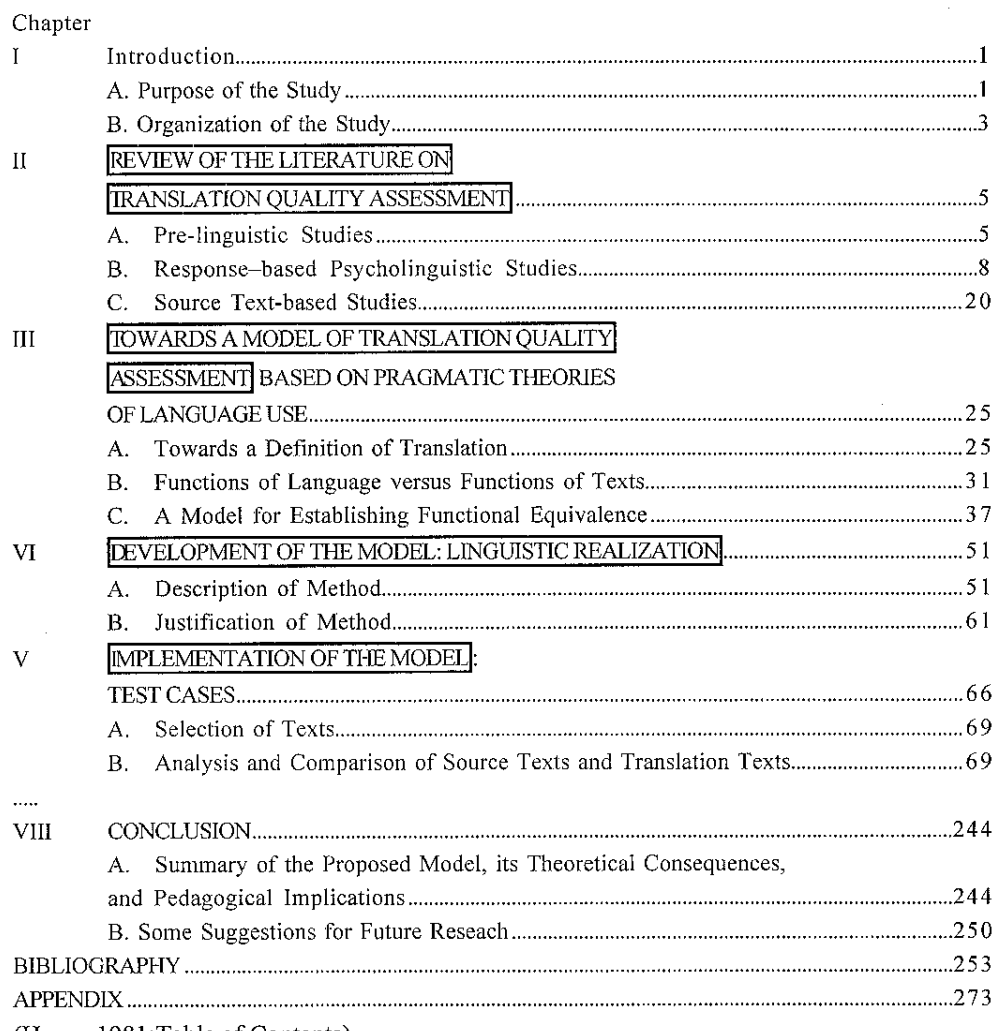

(House 1981:Table of Contents)

10 Presenting a text as an example would take up too much space in this paper. We have, therefore, chosen a 'Table of Contents' which presents an ideal development of thought in the sense of the structural guidelines suggested in this paper. 
The solution proposal is, of course, the most crucial and complex part of writing a theory-related research paper. Some of the most common problems encountered in connection with this section of a paper are:

- lack of positioning one's own approach against that of others (what does it have in common with, how does it differ from other approaches);

- fallacies (false judgements, drawing false conclusions);

- missing or incomplete explications of concepts.

A lack of positioning may lead to misrepresentations in that one (usually the author's own) approach is presented without stating the limits of its scope and applicability. This, in turn, may lead to a general uncritical acceptance of an alleged solution to a problem by others (especially clan-based followers, cf. Gile 1999:30ff.) and may prevent the advancement of further theoretical thought on the subject. Examples are numerous in translation theory and include a wide range of paradigms including machine translation concepts as well as hermeneutic and action theory or functional approaches. ${ }^{11}$

Not defining or explicating the concepts used or established by an author may lead to alternate and/or even random usage of a term, resulting in fallacies in subsequent theoretical debates. This, in turn may lead to confusion and misconceptions about the theorems developed on the basis of a basic yet insufficiently defined notion. A well-known example for such confusion is the so-called 'controversy' over the concept of equivalence, which indeed is largely based on misunderstandings of the basic concept as a result of lacking explications (cf. Gerzymisch-Arbogast 2001).

11 It would therefore be a worthwhile undertaking to position the various approaches in translation theory against each other in the sense of a documented critical bibliography (not as a clan-based untertaking which exists in many variations). An example of good practice is the commented bibliography on text types and text type linguistics by Adamzik (1995), which - despite its relevance for translation - is hardly ever quoted in the translation theory literature. 


\subsubsection{Validity Test}

With a validity test an author (and his/her readers) can control whether his/her own (new) theory or approach fulfills the postulates underlying the development of his/her own solution proposal and whether it indeed closes the deficit analyzed prior to developing this solution.

This paper is an example of a missing 'validity test' because - for space and other reasons - it does not present data against which a validity text could be measured but uses (random) examples instead. Examples, however, are no valid substitution and are inherently dangerous if taken or presented as validity proof because they are generally not representative. When using examples, therefore, their function needs to be disclosed (cf. footnote 3 ), i.e. it needs to be indicated that they are given for illustrative purposes only.

\subsection{Organization of the Concluding Remarks}

It is assumed that in the concluding remarks the ideal expert reader expects a summary of what has been said before, i.e. a brief statement of whether and how the paper realized what it set out to do (its objective). A perspective of the paper's value for furture research is often included and appreciated. The function of this information is to allow for partial reading in that it enables the reader to quickly grasp the basic concepts covered and problems tackled in the paper and facilitates the decision of whether to read the paper in its totality or not.

The main problems with writing 'concluding remarks' are related to introducing new information or hypotheses and presenting general information that blurs the specific points made or objectives attained in the paper and thus may lead to an underestimation of its value.

Example (3) of a norm-compliant conclusion:

English Original

I have presented four concepts that can be used to detect gender-specific translations: topos, speech, an argumentational connector and focalization. By using them I have demonstrated that some Dutch translations of Genesis 27 contain gender specific stereotypes to which the source text does not seem to give rise, such as the male participants with life and strength and the female participant with weakness and death, quoting the male and the female participants in stereotyped ways, pushing the female participant in a negative role and the male in a positive, and lending focalization to a male participant.

(de Vries 1995:320) 
The author clearly - albeit concisely - summarizes the contents of her study, nothing more (e.g. in terms of perspectives), but also nothing less.

\section{A Procedural Suggestion: The 'State-of-the-Art Analysis'}

In view of the enormous quantity of literature available, it is often hard to systematize the available literature and extract the essentials from research papers (especially if they do not comply with the norms of academic writing) in an effort to give an 'overview' of the pertinent literature or a 'state-of-the-art' analysis. This, of course, is not only a quantitative problem. It may be even more difficult to critically evaluate and position the different approaches within the pertinent research context and not just list them as a (quantitative) enumeration of summaries of (often randomly) selected authors or papers on a particular subject. A systematic comparative analysis of the pros and cons of a representative variety of approaches constitutes the qualitative problem in writing a 'state-of-the-art' analysis and involves grouping the existing approaches according to the aspects they have in common and according to the aspects in which they differ. This, i.e. the selection of aspects considered in the comparison and the selection of authors, limits the comparative analysis and makes it possible to systematize the procedure. An example of how to set up a list of aspects as a basis for a comparative analysis can be found in Storrer 1992:20ff. (with respect to an evaluation of valency models). While the quantitative problem is relatively easy to solve given today's technology ${ }^{12}$, the qualitative problem involves expertise, discipline and creative thought in that the criteria by which the different approaches can be differentiated and/or grouped together need to be established and systematically applied.

It may, therefore, be helpful to first separate these two problems (quantitative listing and qualitative analysis) and relate them to each other later using a matrix form. We suggest to use an adapted Aspektra matrix (cf. Gerzymisch-Arbogast 1994:44) and list the authors in the vertical axis and the criteria used for the critical analysis on the horizontal axis.

12 There are a number of text retrieval systems available today. Bernard Glock (1994) gives a critical overview. 
The advantage of such a procedure is transparency (of authors analyzed and criteria used) for the reader and a systematic step-by-step procedure for the writer of an academic paper, which he can largely plan and control.

Example of a 'state-of-the-art' matrix on 'translation theory' ${ }^{13}$ :

\begin{tabular}{|c|c|c|c|c|c|c|c|c|}
\hline authors & $\begin{array}{l}\text { product- } \\
\text { oriented }\end{array}$ & $\begin{array}{l}\text { process- } \\
\text { oriented }\end{array}$ & $\begin{array}{l}\text { developed } \\
\text { from a } \\
\text { spectrum of } \\
\text { phenomena }\end{array}$ & $\begin{array}{l}\text { theory- } \\
\text { oriented }\end{array}$ & $\begin{array}{l}\text { intuitively } \\
\text { formulated }\end{array}$ & formalized & $\begin{array}{l}\text { focused on } \\
\text { single } \\
\text { problem }\end{array}$ & $\begin{array}{l}\text { focused on } \\
\text { holistic } \\
\text { patterns }\end{array}$ \\
\hline A & & & & & & & & \\
\hline B & . & & & & & & & \\
\hline $\mathrm{C}$ & & & & & & & & \\
\hline $\mathrm{D}$ & & & & & & & & \\
\hline $\mathrm{E}$ & & & & & & & & \\
\hline $\bar{F}$ & & & & & & & & \\
\hline
\end{tabular}

With respect to establishing academic evaluation criteria, two precautions need to be considered. First, the criteria have to 'disjunct', i.e. they need to be clearly separable from one another so that an evaluation does not show contradicting values for similar categories or criteria. Secondly, not all of the criteria used in the analysis can be established a priori. Rather, most of them are probably isolated while reading and analyzing the literature. It is important though that all criteria are applied to all authors or works listed to make sure that the comparison is systematically valid. If not, the result will be that one author is judged by one criterion, the next by another, resulting in a rather 'impressionistic' picture which bears the danger of only highlighting positive features in one author and only negative features in another. So, if a criterion is added during the procedure, all the authors that were analyzed beforehand (i.e.

13 Of course, this cannot represent an actual state-of-the-art matrix but is just an illustrative example given to exemplify the procedure suggested here. 
without measurement against this criterion) need to be studied again and attributed a value with respect to that newly created criterion.

The idea of a matrix makes it possible - within a research project that proposes a new theory in translation - to make the following norm-compliant statement with respect to a 'state-of-the-art analysis' (using translation theory as an example):

'A-Z authors have published on translation theory. Of those, $\mathrm{X}$ authors have proposed formalized theories. The present study is limited to the consideration of these formalized theories, which are critically reviewed according to the criteria $\mathrm{x}$ to $\mathrm{y}$. On the basis of a comparative analysis of the merits and limitations of the existing theories B - Q, desiderata are developed for a new translation model. It is the objective of the present study to comply with these stated desiderata....'

\section{Concluding Remarks}

In this paper some structural postulates for writing theory-related translation research papers were suggested as an orientation for setting up theoretical research and for organizing theory-related papers, research and/or dissertations. They were structured according to the common categorization of introduction, main part and concluding remarks. Particular attention was given to setting up the 'state-of-the-art' research analysis. As was outlined above, the postulates may vary when individually applied, but are designed to be used as a check list for one's own writings and may also serve as guidelines for advising others when writing research papers or as a standard when having to judge the quality of papers and/or projects such as master's theses or dissertations or research proposals of other experts.

\section{References}

Adamzik, K. (1995). Textsorten - Texttypologie. Eine kommentierte Bibliographie. Studium Sprachwissenschaft. Bd.12. Münster: Nodus.

De Vries, A. (1995). A matter of life and death: Gender stereotypes in some modern Dutch Bible translations. In Snell Hornby, M., Jettmarová, Z. \& Kaindl, K. (eds): Translation as Intercultural Communication. Selected Papers from the EST Congress - Prague. Amsterdam: John Benjamins. 313-321.

Fluck, H. R. ( $\left.{ }^{5} 1996 / 1976\right)$. Fachsprachen. Einführung und Bibliographie. Tübingen:

Francke. (UTB 483). 
Gerzymisch-Arbogast, H. (1994). Übersetzungswissenschaftliches Propädeutikum. Tübingen: Francke. (UTB 1782).

Gerzymisch-Arbogast, H. (2001). Equivalence Parameters and Evaluation. In Meta (forthcoming).

Gerzymisch-Arbogast, H. (forthcoming). Writing a T\&I Dissertation - Problems, Concerns and Suggestions. In Gile, D. et al. (forthcoming).

Gile, D. (1991). Methodological Aspects of Interpretation (and Translation) Research. In Target. International Journal of Translation Studies. (1991) 3. Amsterdam: John Benjamins. 153-174.

Gile, D. (1999). Use and misuse of the literature in interpreting research. In The Interpreters Newsletter 9/1999. Trieste: Scuola Superiore di Lingue Moderne per Interpreti e Traduttori. 29-43.

Gile, D., Dam, H., Dubslaff, F., Martinsen, B. \& Schjoldager, A. (eds.) (forthcoming). Getting started in interpreting research.

Glock, B. (1994). Help in managing scientific literature. In Scientific Computing World. Nov. 1994. 31-35.

Grice, H.P. (1975). Logic and Conversation. In Cole, P. \& Morgan, J.L. (eds.): Syntax and Semantics. New York: Academic Press. Vol.I. 41-58.

House, J. (1981). A Model for Translation Quality Assessment. Tübingen: Narr. (TBL. $88)$.

Mudersbach, K. (1999). Richtlinien zum Schreiben von wissenschaftlichen Publikationen - Kurzfassung. In Gerzymisch-Arbogast, H., Gile, D., House, J. \& Rothkegel, A. (Hrsg.). Wege der Übersetzungs- und Dolmetschforschung. Tübingen: Narr. (Jahrbuch Übersetzen und Dolmetschen. 1/1999). 316-319.

Sami, Fadia (1999). Zur Wechselwirkung situativer und kognitiver Parameter beim faceto-face-Dolmetschen. In Gil, A., Haller, J., Steiner, E. \& Gerzymisch-Arbogast, H. (Hrsg.): Modelle der Translation. Grundlagen für Methodik, Bewertung, Computermodellierung. Frankfurt: Lang. (SABEST - Saarbrücker Beiträge zur Sprach- und Translationswissenschaft. 1). 241-259.

Sonderforschungsbereich 538. Mehrsprachigkeit. Informationsbroschüre (1999). Hrsg. v. Universität Hamburg. Hamburg.

Standop, E. et al. ( $\left.{ }^{B} 1998\right)$. Die Form der wissenschaftlichen Arbeit. Tübingen: Quelle \& Meyer. (UTB 272).

Storrer, A. (1992). Verbvalenz. Theoretische und Methodische Grundlagen ihrer Beschreibung. Tübingen: Niemeyer.

Theisen, M. R. (1992). Wissenschaftliches Arbeiten. Technik - Methodik - Form. 6. Aufl. München: Vahlen. 


\section{When Talk is a Science...}
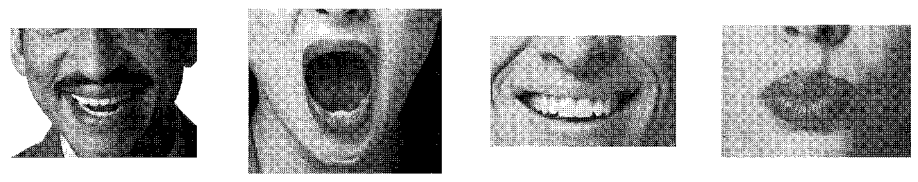

\section{hinguistics and Language Behavior Abstracts}

Comprehensive, cost-effective, timely coverage of current ideas in linguistics and language research

Abstracts of articles, books, and conference papers from nearly 1,500 journals published in 35 countries; citations of relevant dissertations as well as books and other media.

Available in print or electronically through the Internet Database Service from Cambridge Scientific Abstracts (www.csa.com).

Contact sales@csa.com for trial Internet access or a sample issue.

\section{Linguistics \& Language Behavior Abstracts}

\section{Published by CSA}

\section{Cambridge Scientific Abstracts}

